\title{
Association between Vitamin D Level, Vitamin D Receptor Gene Polymorphisms, and Cathelicidin Level to Acute Lower Respiratory Infections, and the Picture of Exon 2-Vitamin D Receptor Gene Polymorphisms in Children under 5 years old
}

\author{
Ida Bagus Subanada ${ }^{1 *}$, I. Made Bakta ${ }^{2}$, I. Wayan Bikin Suryawan ${ }^{3}$, Putu Astawa ${ }^{4}$, Bagus Komang Satriyasa ${ }^{5}$ \\ ${ }^{1}$ Department of Pediatric, School of Medicine, Universitas Udayana, Sanglah General Hospital, Denpasar, Bali, Indonesia; \\ ${ }^{2}$ Department of Internal Medicine, School of Medicine, Universitas Udayana, Sanglah General Hospital, Denpasar, Bali, \\ Indonesia; ${ }^{3}$ Department of Pediatric, Wangaya Hospital Denpasar, Bali, Indonesia; ${ }^{4}$ Department of Orthopaedic, School of \\ Medicine, Universitas Udayana, Sanglah General Hospital Denpasar, Bali, Indonesia; ${ }^{5}$ Department of Pharmacology, School \\ of Medicine, Universitas Udayana Denpasar, Bali, Indonesia
}

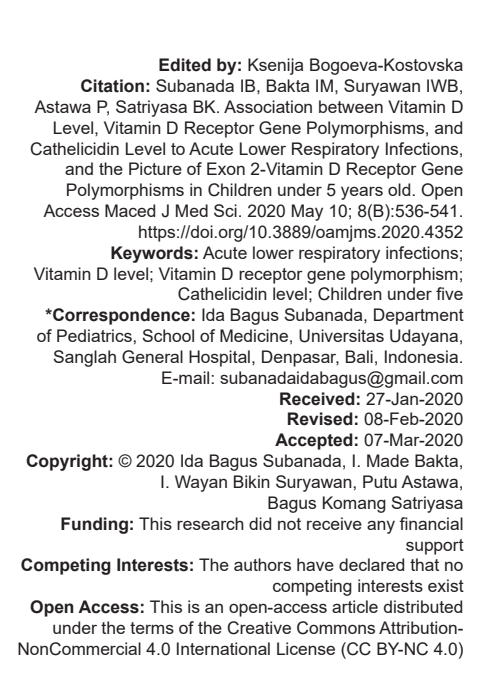

\section{Abstract}

BACKGROUND: Acute lower respiratory infections (ALRIs) are infectious diseases with high morbidity and mortality in children under five. There are several factors associated with ALRIs (bronchiolitis or pneumonia) that have been established. In recent years, Vitamin D level, Vitamin D receptor (VDR) gene polymorphism, and cathelicidin level are also associated with ALRIs. Until now, there was no VDR gene other than Fok1 identified at the exon 2-VDR gene.

OBJECTIVE: The objective of this study was to establish whether Vitamin D deficiency, ff genotype-Fok1 VDR gene polymorphism, and low levels of cathelicidin are risk factors of ALRIs and to determine the pictures of exon 2-VDR genes polymorphisms in children under five.

METHODS: A matched case-control study was conducted in children under the age of five. There were 35 subjects who suffered from bronchiolitis or pneumonia and 35 healthy subjects as a control group. These groups were matched based on age and gender, and the children originated from the same neighborhood. Level of $25(\mathrm{OH}) \mathrm{D}$ exon 2-VDR genes sequencing, and level of cathelicidin were investigated. Data were analyzed by the Chi-square test or Fisher exact test and logistic regression with a significant level of $p<0.05$

RESULTS: This study found that Vitamin D deficiency and low levels of cathelicidin were risk factors of ALRIs (odds ratio $[\mathrm{OR}]=5.82[95 \%$ confidence interval $[\mathrm{Cl}]=1.71-19.89], \mathrm{p}=0.005$ and $\mathrm{OR}=4.07[95 \% \mathrm{Cl}=1.10-15.12]$ $p=0.036$, respectively), while ff genotype-Fok1 VDR gene polymorphism was not $(\mathrm{OR}=1.12[95 \% \mathrm{Cl}=0.26-4.86]$, $p=1.000)$. Fok1 VDR gene polymorphism was the picture of exon 2-VDR gene polymorphisms.

CONCLUSION: It is concluded that Vitamin D deficiency and low levels of cathelicidin are risk factors, but $f f$ genotype-Fok1 VDR gene polymorphism is not a risk factor of ALRIs. Fok1 VDR gene polymorphism is the picture of exon 2-VDR genes polymorphisms.

\section{Introduction}

Bronchiolitis and pneumonia are two of the most common acute lower respiratory infections (ALRIs) in children under the age of five. The World Health Organization estimates about 150 million new cases of bronchiolitis every year, $95 \%$ of which occur in developing countries, and approximately 11-20 million $(7-13 \%)$ require hospitalization [1]. Pneumonia is a high morbidity illness. The worldwide incidence of pneumonia in children under five in 2010 was 120 million, and 14 million of which progressed to severe pneumonia [2]. The mortality rate of bronchiolitis ranged from $0.2 \%$ to $7 \%$ [1], while the mortality rate of pneumonia is much higher. In 2011, the mortality rate of pneumonia was 1.3 million [3] and 1.1 million in 2013 [4]. Ninety-nine percent of children under five who died due to pneumonia occur in developing countries [5]. In Indonesia, the mortality rate of pneumonia during 2012 was $13.2 \%$ [6].

There are several factors associated with ALRIs (bronchiolitis or pneumonia) [7], [8], [9], [10], [11], [12] Some micronutrients, including Vitamin $\mathrm{D}$, are also associated withALRIs. Three studies reportthat Vitamin D is a protective factor of ALRIs [13], [14], [15], while other studies show no association between low Vitamin $D$ intake and bronchiolitis [16], and no association between Vitamin D levels and ALRIs [17], [18].

InadditiontolowVitaminDlevel[13],[14],[15],[19], other factors associated with ALRIs are Vitamin D receptor (VDR) gene polymorphisms [20], [21], [22], and cathelicidin (formed through the role of Vitamin $D$ ) level [23], [24], [25]. Different results are shown for VDR gene polymorphisms [26] and cathelicidin level [27]. 
In addition to inconsistent results, all previous studies were conducted in subtropical countries on white or black ethnic subjects. We know that there is a difference in the time of sunlight exposure between the subtropical and tropical countries [28], and there is a difference in the skin's ability to synthesize Vitamin D due to skin color [29], and there are ethnic variations on VDR gene polymorphisms [30]. Until recently, there has been no study in children simultaneously investigates the association between Vitamin D level, VDR gene polymorphism, and cathelicidin level with ALRIs, and there are no VDR genes, other than Fok1 that has been identified at exon 2-VDR gene. Therefore, this study was aimed to evaluate, whether Vitamin D deficiency, ff genotypeFok1 VDR gene polymorphism, and low levels of cathelicidin were risk factors of ALRIs, and to find out the presence of other gene polymorphisms in addition to Fok1 at exon 2-VDR gene.

\section{Methods}

This was a case-control study, performed at the Department of Child Health, Udayana University Medical School/Sanglah Hospital Denpasar. This study was conducted from April to October 2015 after approval from the Research Ethics Committee Udayana University Medical School/Sanglah Hospital Denpasar.

Samples for case and control groups were selected by consecutive sampling. We calculated sample size based on $\alpha=0.05$ and $\beta=10 \%$ (power $90 \%$ ) and found that the largest sample for three variables (Vitamin D deficiency, ff genotype-Fok1 VDR gene polymorphism, and low levels of cathelicidin) was 35 for each group. The parent or guardian of each subject gave informed consent. The inclusion criteria for the case group were children under five who suffered from hospitalized bronchiolitis or community-acquired pneumonia, while the inclusion criteria for the control group were healthy children under five who matched the case group in terms of age and sex and came from the same neighborhood. The exclusion criteria for the case group were subjects that suffered from congenital heart disease (CHD), immune deficiency, malnutrition, obesity, cerebral palsy, Vitamin A deficiency, and history of taking medications that contain Vitamin D since the acute respiratory infection (ARI) symptoms begin, or the parent refused to participate, while the exclusion criteria for the control group were the parent refused to participate.

Vitamin $D$ and cathelicidin levels were investigated by enzyme-linked immunosorbent assay methods at Prodia Laboratory. The Vitamin $D$ level was defined as deficient if the calcidiol level $\leq 20 \mathrm{ng} / \mathrm{ml}$ [31], [32], while the cathelicidin level was defined as low if the level of cathelicidin $<50 \mathrm{ng} / \mathrm{mL}$ [33]. VDR gene polymorphisms were investigated by Sanger's methods at Biochemistry and Genetic Science Laboratories, and the genotypes (ff, Ff, and FF) were investigated at Fok1 single nucleotide polymorphisms subject [21]. Bronchiolitis referred to the first episode of acute wheezing in children $<2$ years of age, starting as a viral upper respiratory infection (rhinorrhea, cough, or low-grade fever) [9], while pneumonia was established based on the presence of fever, cough, tachypnea, respiratory distress, crackles on chest auscultation, and infiltrates or consolidation on a chest radiograph [10], [12]. Subject characteristics and outcomes were initially analyzed by the Chi-square test or Fisher exact test and then continued by multivariable logistic regression analysis for variables that statistically significant at bivariate analysis. We also performed a subgroup analysis for the variable that statistically significant when be tested by bivariate analysis. $p<0.05$ was considered statistically significant. All data were processed using computer software SPSS 23.0.

\section{Results}

During the study period, there were 63 subjects that met the inclusion criteria for the case group and 44 subjects for the control group. For the case group, 28 subjects were excluded due to CHD (three subjects), obese (one subject), parents refused to participate (eight subjects), cerebral palsy (three subjects), immune deficiency (five subjects), malnutrition (six subjects), and two subjects had a history of taking vitamins since the ARI symptoms began. In the control group, nine subjects were excluded due to parents refused to participate in this study. Of the 35 case subjects, we obtained, 22 subjects suffered from bronchiolitis, and 13 subjects suffered from pneumonia.

Overall, we found that $80 \%$ of subjects were $2-11$ months of age and $63 \%$ were male. There were no differences in characteristics between case and control groups except crowded residential environments (Table 1).

Table 1: Characteristics of the study subjects

\begin{tabular}{llll}
\hline Variables & Case $(\mathrm{n}=35)$ & Control $(\mathrm{n}=35)$ & $\mathrm{p}$ \\
\hline 1. Age (2-11 months), $\mathrm{n}(\%)$ & $28(80)$ & $28(80)$ & $1.000^{\mathrm{a}}$ \\
2. Sex (male), $\mathrm{n}(\%)$ & $22(63)$ & $22(63)$ & $1.000^{\mathrm{a}}$ \\
3. Nutritional status, $\mathrm{n}(\%):$ & & & \\
$\quad$ Underweight+overweight & $10(29)$ & $8(23)$ & $0.584^{\mathrm{a}}$ \\
4. LBW history, $\mathrm{n}(\%)$ & $6(17)$ & $4(11)$ & $0.495^{\mathrm{a}}$ \\
5. Preterm delivery, $\mathrm{n}(\%)$ & $6(17)$ & $4(11)$ & $0.495^{\mathrm{a}}$ \\
6. Non-exclusive breastfeeding, $\mathrm{n}(\%)$ & $23(66)$ & $22(63)$ & $0.803^{\mathrm{a}}$ \\
7. Non-complete immunization status, $\mathrm{n}(\%)$ & $22(63)$ & $19(54)$ & $0.467^{\mathrm{a}}$ \\
8. Indoor air pollution, $\mathrm{n}(\%)$ & $9(26)$ & $6(17)$ & $0.382^{\mathrm{a}}$ \\
9. Crowded residential environment, $\mathrm{n}(\%)$ & $14(40)$ & $3(9)$ & $0.002^{\mathrm{a}}$ \\
10. Cigarette smoke exposure, $\mathrm{n}(\%)$ & $17(49)$ & $13(37)$ & $0.334^{\mathrm{a}}$ \\
11. Asthma, $\mathrm{n}(\%)$ & $1(3)$ & - & $1.000^{\mathrm{b}}$ \\
12. Day care attendance, $\mathrm{n}(\%)$ & $1(3)$ & - & $1.000^{\mathrm{b}}$ \\
\hline The only significant $\mathrm{p}$ value in this characteristic is the crowded residential environment with $\mathrm{p}=0.002$. \\
${ }^{\mathrm{a}}$ Chi-square test, ${ }^{\mathrm{b}}$ Fisher exact test. \\
\end{tabular}


We found that 27 subjects in the case and eight subjects in control groups were Vitamin D deficiency. Bivariate analysis showed that Vitamin $D$ deficiency was a risk factor of ALRIs. Subgroup analysis found that Vitamin $D$ deficiency was a risk factor for bronchiolitis but questionable for pneumonia (Table 2).

Table 2: Risk of ALRIs, bronchiolitis, and pneumonia in Vitamin $D$ deficiency subject

\begin{tabular}{llll}
\hline Case & Control & $\mathrm{OR}(95 \% \mathrm{Cl})$ & $\mathrm{p}$ \\
\hline 27 & 8 & $11.39(3.73-34.76)$ & $<0.0001^{\mathrm{a}}$ \\
19 & 5 & $21.59(4.46-103.90)$ & $<0.0001^{\mathrm{b}}$ \\
8 & 3 & $5.33(0.97-29.39)$ & $0.047^{\mathrm{C}}$ \\
\hline \multicolumn{2}{l}{ The analysis showed that Vitamin D deficiency significantly was a risk factor for bronchiolitis but }
\end{tabular}
questionable for pneumonia. ${ }^{\mathrm{a}} \mathrm{ALRIs},{ }^{\mathrm{b}} \mathrm{Bronchiolitis,}{ }^{\mathrm{C} P n e u m o n i a .}$ ALRIs: Acute lower respiratory infection OR: Odds ratio, Cl: Confidence interval.

After sequencing the PCR of the exon 2-VDR gene using primer reverse, no other genes obtained in addition to the Fok1 VDR gene. Nine (12.9\%) subjects showed ff genotype, $25(35.7 \%)$ subjects showed Ff genotype, and 36 (51.4\%) subjects showed FF genotype. We found that both $f f$ and $F f$ genotypes were not risk factors of ALRIs compared to the FF genotype (Table 3).

Table 3: Risk of ALRIs based on the genotype of Fok1 VDR gene polymorphisms

\begin{tabular}{lllll}
\hline Fok1 VDR gene polymorphisms & $\begin{array}{l}\text { Case } \\
(\mathrm{n}=35)\end{array}$ & $\begin{array}{l}\text { Control } \\
(\mathrm{n}=35)\end{array}$ & OR $(95 \% \mathrm{Cl})$ & $\mathrm{p}$ \\
\hline ff genotype & 5 & 4 & $1.12(0.26-4.86)$ & $1.000^{\mathrm{b}}$ \\
Ff genotype & 11 & 14 & $0.70(0.25-1.96)$ & $0.500^{\mathrm{a}}$ \\
FF genotype & 19 & 17 & 1.00 (reference) & - \\
\hline ff and Ff genotypes were not risk factors of ALRIs compared to the $F F$ genotype (p>0.05). ${ }^{\mathrm{a} C h i-s q u a r e ~ t e s t, ~}$ \\
${ }^{\mathrm{b}}$ Fisher exact test. ALRIs: Acute lower respiratory infections, VDR: Vitamin D receptor.
\end{tabular}

We found that 25 subjects in the case and seven subjects in control groups were low levels of cathelicidin. Bivariate analysis showed that low levels of cathelicidin were a risk factor of ALRIs. Subgroup analysis found that low levels of cathelicidin were a risk factor for bronchiolitis and pneumonia (Table 4).

Table 4: Risk of ALRIs, bronchiolitis, and pneumonia in lowlevel cathelicidin subjects

\begin{tabular}{llll}
\hline Case & Control & OR $(95 \% \mathrm{Cl})$ & $\mathrm{p}$ \\
\hline 25 & 7 & $10.00(3.31-30.23)$ & $<0.0001^{\mathrm{a}}$ \\
16 & 4 & $12.00(2.86-50.31)$ & $<0.0001^{\mathrm{b}}$ \\
9 & 3 & $7.50(1.31-43.03)$ & $0.018^{\mathrm{c}}$ \\
\hline Low levels of cathelicidin were a risk factor for bronchiolitis and pneumonia ( $\mathrm{p}<0.0001) .{ }^{\mathrm{a}} \mathrm{ALRIs}$ \\
'Bronchiolitis, ${ }^{\mathrm{C}}$ Pneumonia. ALRIs: Acute lower respiratory infections, OR: Odds ratio, Cl: Confidence \\
interval.
\end{tabular}

Logistic regression analysis found that both Vitamin D deficiency and low levels of cathelicidin were risk factors of ALRIs (Table 5).

Table 5: Logistic regression multivariable analysis of ALRIs risk factors

\begin{tabular}{lccc}
\hline Variables & OR & $95 \% \mathrm{Cl}$ & $\mathrm{p}$ \\
\hline Vitamin D deficiency & 5.82 & $1.71-19.89$ & 0.005 \\
Low level of cathelicidin & 4.07 & $1.10-15.12$ & 0.036 \\
Crowded residential environment & 2.13 & $0.41-11.06$ & 0.368 \\
\hline Both Vitamin D deficiency and low levels of cathelicidin were risk factors of ALRIs ( $\mathrm{p}<0.05)$. ALRIs: Acute
\end{tabular}

lower respiratory infections, OR: Odds ratio, $\mathrm{Cl}$ : Confidence interval.

\section{Discussion}

In children under five, ALRIs are ARI with a fairly high incidence and high mortality rate (especially pneumonia with a mortality rate of 1.1 million in 2013) [4]. There are several factors associated with ALRIs [7], [8], [9], [10], [11], [12]. We found that all of them were comparable in case and control groups except the crowded residential environment (Table 1). The crowded residential environment will facilitate germ transmission from one subject to another subject.

In addition to the role of calcium and bone metabolisms [34], in recent years, Vitamin $D$ is also considered to play an important role in several diseases, including ALRIs. Calcidiol is the best indicator to determine total Vitamin $D$ status in the body, although the biologically active form of Vitamin $D$ is calcitriol [35], [36]. This study found that Vitamin D deficiency was a risk factor of ALRIs. Similar results are shown in other studies [13], [14], [15], [25], [37].

A different result was shown by Roth et al. [17] who found that the mean calcidiol levels were similar between case groups (ALRIs patients mainly bronchiolitis) and control (healthy children) groups (77 nmol/L vs. $77.2 \mathrm{nmol} / \mathrm{L}, \mathrm{p}=0.960)$. They did not analyze the role of the 1-OHase enzymes, VDR gene polymorphisms, and cathelicidin levels. Another study by Leis et al. [16], in a post hoc analysis, found that Vitamin $D$ intake $<80 \mathrm{IU} / \mathrm{kg} /$ day was not a risk factor for bronchiolitis (odds ratio [OR] $=1.7$ (95\% confidence interval [Cl] 0.7-4.0]), but a risk factor for pneumonia $(\mathrm{OR}=7.9[95 \% \mathrm{Cl}$ 1.8-35.5]). The difference in results may be due to the difference in methods. Leis et al. [16] only measured Vitamin D intake, they did not measure calcidiol levels. The disruption of enzymes involved in the metabolism of Vitamin D, such as 25-OHase or 1-OHase enzymes, will influence calcidiol or calcitriol production that will also lead to cathelicidin production during adequate Vitamin D intake. In addition, Leis et al. [16] did not investigate the role of VDR gene polymorphisms. The difference in the genotype of the Fok1 VDR gene also influences the incidence of ALRIs [22].

Subgroup analysis of our study found that Vitamin $D$ deficiency has a greater effect size for bronchiolitis than pneumonia. This result may be due to the cause of bronchiolitis, generally virus, especially respiratory syncytial virus (RSV), while pneumonia can be caused by a bacteria or virus. Litonjua [38] stated that Vitamin $D$ reduces the inflammation that occurs after viral (RSV) infection.

VDR gene polymorphisms are also associated with ALRIs. VDR gene instructs the body to make a protein called VDR that will enable the body to respond to Vitamin D [39]. In some ethnicities, VDR is highly polymorphic. There are several polymorphisms that have been reported for the VDR gene; one of them is Fok1 that is located at exon 2 [40]. Polymorphisms in Fok1 occur due to changes in the thymine/cytosine (T/C) sequence [41] with basic alteration on codon ATG to ACG at the first potential start site [42]. Based on gene sequencing at exons 2, we found only Fok1 VDR gene polymorphisms. 
The Fok1 VDR gene consists of three genotypes, that is, ff, Ff, and FF. The ff genotype is less active in transcription the cathelicidin gene and will lead to low cathelicidin levels, and therefore a higher risk to suffer from ALRIs [22]. The short 424 amino acid (aa) VDR protein variant (the "C" allele or " $F$ " allele) has greater activity (1.7 times) than long 427 a variant (the "T" allele or " $f$ " allele) in its transactivation capacity as a transcription factor [41]. This study found that the ff genotype-Fok1 VDR gene was not a risk factor of ALRIs compared to the FF genotype. These results support a previous study that found no difference between VDR gene polymorphisms in children with recurrent tonsillopharyngitis compared to healthy children [26]. Different results were obtained by Roth et al. [21] who conducted a case-control study in children aged 1-24 months. They observed that the ff genotype-Fok1 VDR gene was a risk factor of ALRIs (predominant bronchiolitis) compared to the FF genotype (OR $=7.38$ [95\% Cl $=1.17-46.55], p=0.033)$. The difference in results occurs due to the control subjects. The control subject of our study was healthy subjects during the study period (that perhaps previously had ALRIs), while Roth et al. [21] used 1-24 months age subjects that were hospitalized for surgical reasons, without a history of hospitalization due to ALRIs. Another possible cause of the different results is the differences in ethnicity.

Our study also found that low levels of cathelicidin were 4 times more likely to cause ALRIs. Similar results are shown in other studies. Albanna et al. [25] performed a case-control study in Egyptian children and found that children with cathelicidin levels $<20 \mathrm{ng} / \mathrm{mL}$ were risk factor for pneumonia compared to children with cathelicidin levels $>20 \mathrm{ng} / \mathrm{mL}(\mathrm{OR}=10.33[95 \% \mathrm{Cl}=3.31-33.62]$, $p<0.001)$. A study on adults reported higher rates of death from infectious disease in subjects who have low levels of circulating cathelicidin (OR $=3.7[95 \% \mathrm{Cl}=1.2-11.2])$ [24].

Cathelicidin has broad-spectrum antimicrobial activity against microorganisms [43], [44]. Transcription of cathelicidin antimicrobial peptide (CAMP) is increased during bacteria, viruses, fungi, or protozoa infections [45]. The antigen of these agents will activate toll-like receptor-2; this receptor then triggers response mediated by Vitamin $D$ in the form of the interaction between calcitriol and VDR. This interaction will activate CAMP genes to express cathelicidin. This evidence makes Vitamin $D$ as an important factor in the regulation of cathelicidin and can explain the antimicrobial role of Vitamin D [33], [46].

In contrast to our study, Leow et al. [27] performed a cohort study in adults with pneumonia that was selected by convenient sampling and found that cathelicidin and $\beta$-defensin- 2 cannot predict mortality. Differences in results may be due to differences in age (children are not representative of adults), outcomes, and sample selection.

On subgroup analysis, we found that low levels of cathelicidin have a greater effect size in for bronchiolitis than pneumonia. This result was consistent with the results of the subgroup analysis for Vitamin D levels. Some studies have shown a positive correlation between the levels of Vitamin D and cathelicidin [25], [45], [47]. Greater effect size in bronchiolitis than pneumonia is possibly due to the proportion of the virus causing bronchiolitis that is greater than the proportion of the virus causing pneumonia. Miller et al. [48] reported that the causes of bronchiolitis are RSV $(76 \%)$, human rhinovirus (18\%), influenza virus (10\%), human metapneumovirus (3\%), coronavirus $(2 \%)$, and parainfluenza virus (PIV) $1 \%$, while only $30 \%$ of pneumonia are caused by viruses [49], of which $20 \%$ due to RSV, $3 \%$ by the influenza virus, and $7 \%$ due to PIV [10]. RNA virus will increase active Vitamin $D$ on epithelial cells of the respiratory system and expression of cathelicidin (this does not happen on bacterial antigen wall component). Vitamin D will upregulate cathelicidin expression in the epithelial cells of the respiratory system and plays an important role in host defense. Vitamin $D$ also activates the secretion of $\beta$-defensin- 2 from neutrophils. Betadefensin-2 has activity against RSV, influenza virus, PIV, and adenovirus [50].

As far as we know, this is the first study that simultaneously identifies the association between Vitamin D deficiency, Fok1 VDR gene polymorphism, and low levels of cathelicidin with ALRIs in children under five. This study also found Vitamin D deficiency and low levels of cathelicidin as a risk factor for ALRIs with a different cut off point to the previous studies and also got a greater effect size for bronchiolitis than pneumonia.

This study had several limitations, such as control patients not being assessed for history of ALRI, infection cause (viral or bacterial) not being investigated, and calcium, parathyroid hormone, and 1-OHase levels not being measured.

\section{Conclusion}

Finally, we conclude that Vitamin D deficiency and low levels of cathelicidin are risk factors, but ff-genotype-VDR gene polymorphisms are not a risk factor of ALRIs. Subjects with Vitamin D deficiency or low levels of cathelicidin have a greater risk of suffering from bronchiolitis than pneumonia. Fok1 VDR gene is the only picture of exon 2-VDR gene polymorphisms. To prevent Vitamin $D$ deficiency, we suggest that sun exposure during the daytime is essential (4-10 min for white ethnics, 60-80 min for black ethnics, and among for brown skin) [29], children under five must have a diet that contains $400 \mathrm{IU} /$ day of Vitamin D [31] and occasionally measure Vitamin D levels in children. Further studies are needed to examine calcium, 
parathyroid hormone, and 1-OHase enzyme and the control selection using children that have never suffered from ALRI.

\section{References}

1. DeNicola LK, Maraqa NF, Custodio HT. Bronchiolitis. Available from: http://www.emedicine.medscape.com/article/961963overview\#a0156. [Last accessed on 2013 Dec 10].

2. Walker CL, Rudan I, Liu L, Nair H, Theodoratou E, Bhutta ZA, et al. Global burden of childhood pneumonia and diarrhoea. Lancet. 2013;381(9875):1405-16. https://doi.org/10.1016/ s0140-6736(13)60222-6

PMid:23582727

3. United Nations Children's Fund (UNICEF). Committing to Child Survival: A Promise Renewed. Progress Report; 2012. Available from: http://www.worldpneumoniaday.org. [Last accessed on 2013 Dec 01].

4. WHO. Pneumonia Still Responsible for One $5^{\text {th }}$ of Child Deaths. Available from: http://www.int/mediacentre/news/releases/2013/ world-penumonia-day-201311122/en. [Last accessed on 2014 Jul 25].

5. United Nations Children's Fund (UNICEF). Pneumonia and Diarrhea: Tackling the Deadliest Disease for the World's Poorest Children; 2012. Available from: http://www.worldpneumoniaday. org. [Last accessed on 2013 Dec 01]

6. Departemen Kesehatan Indonesia. Profil Kesehatan Indonesia 2012. Jakarta: Departemen Kesehatan Indonesia; 2013.

7. Mayo-Wilson E, ImdadA, HerzerK, Yakoob MY, BhuttaZA. Vitamin A supplements for preventing mortality, illness, and blindness in children aged under 5: Systematic review and meta-analysis. BMJ. 2011;343:d5094. https://doi.org/10.1136/bmj.d5094 PMid:21868478

8. Watts KD, Goodman DM. Wheezing in infant: Bronchiolitis. In: Kliegman RM, Stanton BF, Geme JW, Schor NF, Behrman RE, editors. Nelson Textbook of Pediatrics. $19^{\text {th }}$ ed. Philadelphia, PA: Saunders; 2011. p. 1456-9. https://doi.org/10.1016/ b978-1-4377-0755-7.00714-4

9. Ali S, Plint AC, Klassen TP. Bronkiolitis. In: Wilmott RW, Chernick V, Boat TF, Deterding RR, Bush A, Ratjen F, editors. Kendig and Chernick's Disorders of The Respiratory Tract in Children. $8^{\text {th }}$ ed. Philadelphia, PA: Saunders; 2012. p. 443-52. https://doi.org/10.1016/b978-1-4377-1984-0.00081-4

10. Crowe JE. Viral pneumonia. In: Wilmott RW, Chernick $P$, Boat TF, Deterding RR, Bush A, Ratjen F, editors. Kendig and Chernick's Disorders of the Respiratory Tract in Children. $8^{\text {th }}$ ed. Philadelphia, PA: Saunders; 2012. p. 453-60. https://doi. org/10.1016/b978-1-4377-1984-0.00081-4

11. Jackson S, Mathews KH, Pulanic D, Falconer R, Rudan I, Campbell $\mathrm{H}$, et al. Risk factors for severe acute lower respiratory infection in children-a systematic review and meta-analysis. Croat Med J. 2013;54(2):110-21. https://doi.org/10.3325/ cmj.2013.54.110

PMid:23630139

12. Marostica PJ, Stein RT. Communiy-acquired bacterial pneumonia. In: Wilmott RW, Chernick P, Boat TF, Deterding RR, Bush A, Ratjen F, editors. Kendig and Chernick's Disorders of the Respiratory Tract in Children. $8^{\text {th }}$ ed. Philadelphia, PA: Saunders; 2012. p. 461-72. https://doi.org/10.1016/ b978-1-4377-1984-0.00081-4

13. Roth DE, Shah R, Black RE, Baqui AH. Vitamin D status and acute lower respiratory infection in early childhood in Sylhet,
Bangladesh. Acta Paediatr. 2010;99(3):389-93. https://doi. org/10.1111/j.1651-2227.2009.01594.x

PMid:19900174

14. Belderbos ME, Houben ML, Wilbrink B, Lentjes E, Bloemen EM, Kimpen JLL, et al. Cord blood Vitamin D deficiency is associated with respiratory syncytial virus bronchiolitis. Pediatrics. 2011;127(6):e1513-20. https://doi.org/10.1542/peds.2010-3054 PMid:21555499

15. Camargo CA Jr., Ganmaa D, Frazier AL, Kirchberg FF, Stuart JJ, Kleinman K, et al. Randomized trial of Vitamin D supplementation and risk of acute respiratory tract infection in Mongolia. Pediatrics. 2012;130(3):e561-7. https://doi. org/10.1542/peds.2011-3029

PMid:22908115

16. Leis KS, McNally JD, Montgomery MR, Sankaran K Karunanayake C, Rosemberg AM. Vitamin D intake in young children with acute lower respiratory infection. Transl Pediatr. 2012;1(1):6-14

PMid:26835258

17. Roth $D E$, Jones $A B$, Prosser C, Robinson JL, Vohra S. Vitamin D status is not associated with the risk of hospitalization for acute bronchiolitis in early childhood Vitamin D status and childhood bronchiolitis. Eur J Clin Nutr. 2009;63(2):297-9. https://doi. org/10.1038/sj.ejcn.1602946

PMid:17971825

18. McNally JD, Leis K, Matheson LA, Karuananyake C, SanKaran K, Rosenberg AM. Vitamin D deficiency in young children with severe acute lower respiratory infection. Pediatr Pulmonol. 2009;44(10):981-8. https://doi.org/10.1002/ppul.21089 PMid: 19746437

19. Hewison M. An update on Vitamin $D$ and human immunity. Clin Endocrinol (Oxf). 2012;76(3):315-25.

PMid:21995874

20. White JH. Vitamin D signaling, infectious diseases, and regulation of innate immunity. Infect Immun. 2008;76(9):3837-43. PMid: 18505808

21. Roth DE, Jones AB, Proser C, Robinson JL, Vobra S. Vitamin D receptor polymorphisms and the risk of acute lower respiratory tract infection in early childhood. J Infect Dis. 2008;197(5):67680. https://doi.org/10.1086/527488

PMid: 18266602

22. Bruce D, Ooi JH, Cantoma MT. Vitamin D host resistance to infection? Putting the cart infront of the horse. Exp Biol Med (Maywood). 2010;235(8):921-7. https://doi.org/10.1258/ ebm.2010.010c02

PMid:20660091

23. Bartley J. Vitamin D, innate immunity and upper respiratory tract infection. J Laryngol Otol. 2010;124(5):465-9. https://doi. org/10.1017/s0022215109992684 PMid:20067648

24. Gombart AF, Bhan I, Borregaard N. Low plasma level of cathelicidin antimicrobial peptide (hCAP 18) predicts increased infectious diseases mortality in patients undergoing hemodialysis. Clin Infect Dis. 2009;48(4):418-24. https://doi. org/10.1086/596314 PMid:19133797

25. Albanna EA, Ali YF, Elkashnia RA. Vitamin D and LL-37 in children with pneumonia. Egypt $\mathrm{J}$ Pediatr Allergy Immunol. 2010;8(2):81-6.

26. Yildiz I, Unuvar E, Zeybek U, Toptas B, Cacina C, Toprak S, et al. The role of Vitamin $D$ in children with recurrent tonsillopharyngitis. Ital J Pediatr. 2012;38:25. https://doi. org/10.1186/1824-7288-38-25

PMid:22682426 
27. Leow L, Simpson T, Cursons R, Karalus N, Hancox RJ. Vitamin D, innate immunity and outcomes in community acquired pneumonia. Respirology. 2011;16(4):611-6. https://doi. org/10.1111/j.1440-1843.2011.01924.x

PMid:21244571

28. Holick MF. Vitamin D: A millenium perspective. J Cell Biochem. 2003;88(2):296-307.

PMid:12520530

29. Holick MF. Sunlight and Vitamin D for bone health and prevention of autoimmune diseases, cancers, and cardiovascular disease. Am J Clin Nutr. 2004;80(6):1678S-88. https://doi.org/10.1093/ ajcn/80.6.1678s

PMid:15585788

30. Uitterlinden AG, Fang $Y$, van Meurs JB, Pols HA, van Leeuwen JP. Genetics and biology of Vitamin D receptor polymorphism. Gene. 2004;338(2):143-56. https://doi. org/10.1016/j.gene.2004.05.014

PMid:15315818

31. Holick MF, Binkley NC, Bischoff-Ferrari HA, Gordon CM, Hanley DA, Heaney RP, et al. Evaluation, treatment, and prevention of Vitamin D deficiency: An endocrine society clinical practice guideline. J Clin Endocrinol Metab. 2011;96(7):191130. https://doi.org/10.1210/jc.2011-0385

PMid:21646368

32. Ojaimi S, Skinner NA, Strauss BJ, Sundararajan V, Woolley I, Visvanathan K. Vitamin D deficiency impacts on expression of toll-like receptor-2 and cytokine profile: A pilot study. J Transl Med. 2013;11:176. https://doi.org/10.1186/1479-5876-11-176 PMid:23875738

33. Gombart AF, Borregaard N, Koeffler HP. Human cathelicidin antimicrobial peptide (CAMP) gene is a direct target of the Vitamin $D$ receptor and is strongly up-regulated in myeloid cells by 1,25 dihydroxyvitamin D3. FASEB J. 2005;19(9):1067-77. https://doi.org/10.1096/fj.04-3284com PMid:15985530

34. Finklea JD, Grossmann RE, Tangpricha V. Vitamin D and chronic lung disease: A review of molecular mechanism and clinical studies. Adv Nutr. 2011;2(3):244-53. PMid:22332056

35. Deluca HF, Prahl JM, Plum LA. 1,25-dihydroxyvitamin D is not responsible for toxicity caused by Vitamin $D$ or 25-hydroxyvitamin D. Arch Biochem Biophys. 2011;505(2):22630. https://doi.org/10.1016/j.abb.2010.10.012 PMid:20965147

36. Heaney RP. Vitamin D-baseline status and effective dose. N Engl J Med. 2012;367(1):77-8. PMid:22762324

37. Shin YH, Yu J, Kim KW, Ahn K, Hong SA, Lee E, et al. Association between cord blood 25-hydroxyvitamin D concentrations and respiratory tract infections in the first 6 months of age in a Korean population: A birth cohort study (COCOA). Korean J Pediatr. 2013;56(10):439-45. https://doi.org/10.3345/ kjp.2013.56.10.439

PMid:24244212

38. Litonjua AA. Vitamin D deficiency as a risk factor for childhood allergic disease and asthma. Curr Opin Allergy Clin Immunol. 2012;12(2):179-85. https://doi.org/10.1097/ aci.0b013e3283507927

\section{PMid:22266772}

39. Genetics Home Reference. Your Guide to Understanding Genetics Conditions. VDR-Vitamin D 1,25-dyhidroxyvitamin D3) Receptor. Available from: http://www.ghr.nlm.nih.gov/gene/ VDR. [Last accessed on 2014 Oct 02].

40. Flugge J, Krusekopf S, Goldammer M, Osswald E, Terhalle $\mathrm{W}$, Malzahn $\mathrm{U}$, et al. Vitamin D receptor hapotypes protect against development of colorectal cancer. Eur J Clin Pharmacol. 2007;63(11):997-1005. https://doi.org/10.1007/ s00228-007-0367-4

PMid:17882409

41. Arai $H$, Miyamoto $K$, Taketani $Y$, Yamamoto $H$, lemori $Y$ Morita $\mathrm{K}$, et al. A Vitamin $\mathrm{D}$ receptor gene polymorphism in the translation initiation codon: Effect on protein activity and relation to bone mineral density in Japanese women. J Bone Miner Res. 1997;12(6):915-21. https://doi.org/10.1359/jbmr.1997.12.6.915 PMid:9169350

42. Saijo T, Naito E, Ito M, Takeda E, Hashimoto T, Kuroda Y. Therapeutic effect of sodium dichloroacetate on visual and auditory hallucinations in a patient with MELAS. Neuropediatrics. 1991;22(3):166-7. https://doi.org/10.1055/s-2008-1071436 PMid:1944824

43. Nizet V, Gallo RL. Cathelicidins and innate defence against invasive bacterial infection. Scand J Infect. 2003;35(9):670-6.

PMid:14620153

44. Tomasinsig L, Zanetti M. The cathelicidins. Structure, function, and evolution. Curr Protein Pept Sci. 2005;6(1):23-34.

PMid:15638766

45. Jeng L, Yamshcchikov AV, Judd SE, Blumberg HM, Martin GS, Ziegler TR, et al. Alterations in vitamin D status and anti-microbial peptide levels in patients in the intensive care unit with sepsis. $J$ TransI Med. 2009;7:28. https://doi.org/10.1186/1479-5876-7-28 PMid:19389235

46. Peric M, Koglin S, Kim SM. Enhances Vitamin D-induced expression of cathelicidin antimicrobial peptide in human keratinocytes. J Immunol. 2008;181(12):8504-12. https://doi. org/10.4049/jimmunol.181.12.8504

\section{PMid:19050268}

47. Dixon BM, Barker T, Mckinnon T, Cuomo J, Frei B, Borregaard N et al. Positive correlation between circulating cathelicidin antimicrobial peptide (hCAP18)/LL-37) and 25-hydroxyvitamin D levels in healthy adults. BMC Res Notes. 2012;5:575. https:// doi.org/10.1186/1756-0500-5-575

PMid:23095332

48. Miller EK, Gebretsadik T, Carroll KN, Dupont WD, Mohamed YA, Morin, et al. Viral etiologies of infants bronchiolitis, croup, and upper respiratory illness during four consecutive years. Pediatr Infect Des. 2013;32(9):950-5. https://doi.org/10.1097/ inf.0b013e31829b7e43

PMid:23694832

49. Robinson J. Viral Pneumonia. Available from: http://www. webmd.com/lung/viral-pneumonia-lung infection. [Last accessed on 2016 Jan 09].

50. Schwalfenberg GK. A review of the critical role of Vitamin D in the functioning of the immune system and the clinical implications of Vitamin D deficiency. Mol Nutr Food Res. 2011;55(1):96-108. https://doi.org/10.1002/mnfr.201000174

PMid:20824663 